\title{
Investigation of Some Pesticides' Effects on Activities of Glutathione Reductase and Glutathione S-Transferase Purified from Turkey Liver under in Vitro Conditions"
}

\author{
Pınar GÜLLER ${ }^{1}$, Ebru AKKEMIK² ${ }^{2}$ Sevil KÖR ${ }^{3}$, Mehmet ÇIFTCİ ${ }^{4}$
}

\begin{abstract}
Whereas a very small amount of pesticides which are used for elimination of undesirable species and for a more fertile agriculture reach the target organism, majority of pesticides reach to nontarget organisms. It is foreseen by our team that the pesticides used for various purposes may negatively affect the glutathione mechanism of the organisms. However, determination of effective dosage range is the objective of our study subjects. For this reason, the in vitro effects of widely used pesticides (lambda-cyhalothrin, cypermethrin, chlorpyrifos, dichlorvos, glyphosate isopropylamine) on the activities of glutathione reductase (GR) and glutathione S-transferase (GST) which are two important enzymes of the glutathione system have been investigated in this study. It has been determined that when lambda-cyhalothrin does not affect the GR enzyme purified from the turkey liver, chlorpyrifos, glyphosate isopropylamine, dichlorvos and cypermethrin cause inhibition. When the effects of pesticides on GST enzyme purified from turkey liver were investigated in in vitro conditions, it was determined that all examined pesticides had inhibitory effects. In this context, the potential doses which can create a risk for live life, of pesticides that are commonly used, have been identified.
\end{abstract}

Keywords: Glutathione S-transferase; glutathione reductase; pesticides.

\section{Hindi Karaciğerinden Saflaştırılan Glutatyon Redüktaz ve Glutatyon S-Transferaz Aktiviteleri Üzerine Bazı Pestisitlerin Etkilerinin in Vitro Şartlarda İncelenmesi*}

\begin{abstract}
ÖZET: İstenmeyen türlerin ortadan kaldırılması ve daha verimli bir tarım için kulanılan pestisitlerin, çok küçük bir kısmı hedef organizmaya ulaşırken oldukça büyük bir kısmı da hedef olmayan organizmalara ulaşmaktadır. Çeşitli amaçlarla kullanılan pestisitlerin söz konusu organizmaların glutatyon mekanizmasını olumsuz şekilde etkileyebileceği ekibimiz tarafından öngörülmüş̧ür. Ancak etkili dozaj aralığının tespit edilmesi çalışma konumuzun amacını oluşturmaktadır. Bu nedenle belirtilen çalışmada glutatyon sisteminin iki önemli enzimi olan glutatyon redüktaz (GR) ve glutatyon S-transferazın (GST) aktiviteleri üzerine oldukça yaygın kullanılan pestisitlerin (lambda-sihalotrin, sipermetrin, klorpirifos, diklorvos, glifosat izopropilamin) in vitro etkileri araştırılmıştır. Hindi karaciğerinden saflaştırılan GR enzim aktivitesi üzerine lambda-sihalotrin'nin etki etmediği, klorpirifos, glifosat izopropilaminin, diklorvos ve sipermetrinin ise inhibisyona sebep olduğu tespit edilmiştir. Hindi karaciğerinden saflaştırılan GST enzim aktivitesi üzerine söz konusu pestisitlerin etkileri in vitro şartlarda araştırıldığında ise çalışma kapsamında incelenen tüm pestisitlerin inhibisyon etkisine sahip olduğu belirlenmiştir. Bu kapsamda yaygın olarak kullanılan zirai ilaçların canlı yaşam için risk oluşturabilecek potansiyel dozajları tespit edilmiştir.
\end{abstract}

Anahtar Kelimeler: Glutatyon redüktaz, glutatyon S-transferaz, pestisit.

Pınar GÜLLER (0000-0001-8482-7889), Atatürk University, Science Faculty, Department of Chemistry, Erzurum, Türkiye

Ebru AKKEMIK (0000-0002-4177-4884), Siirt University, Faculty of Engineering and Architecture, Department of Food Engineering, Siirt, Türkiye

Sevil KÖR (0000-0001-6935-2889), Karadeniz Technical University, Faculty of Medicine, Department of Clinical Biochemistry, Trabzon, Türkiye

Mehmet ÇIFTCI (0000-0002-1748-3729), Bingöl University, Faculty of Science and Arts, Department of Chemistry, Bingöl, Türkiye Sorumlu yazar/Corresponding Author: Mehmet ÇİFTCİ, mciftci@bingol.edu.tr

Some part of this work was presented in Chromatography 2011 Congress on 7-10 September 2011 and in Chromatography 2013 Congress on 19-22 June 2013, and it was published in the congress abstract book. 


\section{INTRODUCTION}

In agriculture, several agricultural methods and different components used in this field are required in order to obtain quality products with high efficiency. Pesticide is one of the plant protection products used in this field (Tiryaki et al., 2010). When we reviewed literatures, pesticides are generally described as substances or mixtures which are used in order to prevent and control of harmful organisms or decrease harms of them. It is frequently preferred because of that it affects in a short time and due to ease of use. Whereas pesticide production is about 3.2 million tons annually, cost of pesticide trade is about 44 billion dolars worldwide (Tiryaki et al., 2010; Burçak, 2012). When pesticides are not used in accordance with instructions by unconscious consumers, it causes negative effects on human health and environment (Tiryaki et al., 2010). Whereas 0.015$6.0 \%$ of pesticides that are used as agrochemicals affects through reaching the organism, a part of $94-99.9 \%$ reaches to nontarget organisms in agroecosystem and to the soil or mixes with water as a chemical pollutant through dragging into natural ecosystems in the environment (Yıldız ve ark., 2005; Tiryaki et al., 2010). Pesticide which is taken by living creatures other than the target organizm via different routes leads to oxidative stress (Alaa et al., 2011). Oxidative stress is impairment of the balance between reactive oxygen species and antioxidants on behalf of reactive oxidants (Halliwell., 2007; Kovesdy and Kalantar-Zadeh, 2009; Wildburger et al., 2009; Sabuncuoğlu ve Özgüneş, 2011). Reactive oxygen species affects by causing pathological changes in cellular membrane, cellular organelles and DNAs through oxidation of proteins, lipids, carbohydrates and DNA. As a result of these, functional impairment or cell death may develop or tumor may develop by gaining them mutant features (Dilek, 2003). It is known that oxidative stress triggers many diseases. The leading ones are health problems such as cancer, parkinson, diabetes and premature aging (Bhuvarahamurthy et al., 1979; Romero et al., 1998; Halliwell, 2007; Kovesdy and Kalantar-Zadeh, 2009; Wildburger et al., 2009). In contrary to this, organism has antioxidant mechanisms to protect itself against free radicals it produces and toxic effects of normal oxygen metabolism (Fridovich, 1976). As well as antioxidants can be synthesized in the body, they can be received from diet. Antioxidant defense system in living creatures is divided into two main groups as endogenous and exogenous (Keha ve Küfrevioglu, 2009). The endogenous antioxidant system also includes antioxidant enzymes. In enzymatic defense systems, enzymes such as superoxide dismutase (SOD), catalase (CAT), glutathione peroxidase (GPx), glutathione reductase (GR) and glutathione S-transferase (GST) play roles (Keha ve Küfrevioglu, 2009).

GR (E.C.1.8.1.7), one of the enzymes we work with, catalyzes electron transfer among low- or high-molecular weight disulphide substrates and reduced pyrimidine nucleotides (NADPH) (Keha ve Küfrevioglu, 2009). The most important targets of the reaction catalyzed by GR is to preserve GSH/GSSG (reduced glutathione/oxidized glutathione) rate in cellular media. - $\mathrm{SH}$ groups contained in glutathione protects the cell against destructive effects of oxidizing agents. Therefore, some metabolic impairments may occur in low concentration of glutathione (Keha ve Küfrevioglu, 2009).

Glutathione-S transferases, the other enzyme we work with, is a multifunctional enzyme family involved in detoxification processes via many different mechanisms. These enzymes may catalyze conjugation of electrophilic xenobiotics with GSH and may keep toxic compounds from the cycle via covalent and non-covalent bonds (Hayes and Pulford, 1995). In addition to detoxification of exogenous chemicals, it was observed that they protected the cellular integrity against endogenous oxidative stress through expressing GPx activity via selenium-dependant organic hydroperoxides (Armstrong, 1997).

Agrochemicals which promote development of herbal production by taking undesirable species under control are known to have harmful effects. In this study, we aimed investigation of inhibitory effect of pesticides on activities of two important enzymes (GR and GST) of antioxidant defense system which are purified from turkey liver under in vitro conditions.

\section{MATERIAL AND METHODS}

\section{Materials}

$\beta$-nicotine amide adenine dinükleotide phosphate (reduced form) (NADPH), $\beta$-nicotine amide adenine dinükleotide phosphate (oxidized form) $\left(\mathrm{NADP}^{+}\right.$), oxidized glutathione (GSSG), reduced glutathione (GSH), 1-kloro 2,4 dinitrobenzene (CDNB) was procured from Sigma Chem. Co., 2',5' ADP-Sepharose 
from 4B Pharmacia, Glutathione Agarose from SigmaAldrich and all other chemicals from Sigma and Fluka. Pesticides were procured from the market commercially.

\section{Activity Assays}

Activity assay of GR was performed as described in Carlberg and Mannervik and activity of GST was measured as described in Habig et al., 1974 (Habig et al., 1974; Carlberg and Mannervik, 1975).

\section{Purification of GR and GST from Turkey Liver}

Livers obtained from adult turkeys were washed with an isotonic saline solution containing $1 \mathrm{mM}$ EDTA (ethylenediaminetetraacetic acid), 1mM DTT (1,4dithiothreitol) and $1 \mathrm{mM}$ PMSF before they were used and kept at $-80^{\circ} \mathrm{C}$.

\section{preparation of homogenates}

After the liver which would be used for purification was chopped into small pieces its cellular membranes were decomposed with liquid nitrogen. After that, it was suspended in a $50 \mathrm{mM}$ Potassium phosphate $(\mathrm{pH}$ 7.5) buffer of about 3 -fold volume containing $1 \mathrm{mM}$ DTT, 1mM EDTA and $1 \mathrm{mM}$ PMSF. Suspension was centrifuged at $13000 \times \mathrm{xg}$ and the precipitate was separated. Thus, homogenate was obtained.

\section{purification of GR from turkey liver affinity chromatography}

The purification process was performed as described in Taşer and Ciftci, 2012 by using 2', 5'-ADP Sepharose 4B affinity column (Taşer and Ciftci, 2012).

\section{purification of GST from turkey liver by affinity chromatography}

The purification process was performed as described in Akkemik et al., 2012 by using Glutathione Agarose affinity column (Akkemik et al., 2012).

\section{In Vitro Inhibition Studies}

Inhibitory effects of cypermethrin, chlorpyrifos, glyphosate isoproplyamin, dichlorvos and lambda cyhalotrin pesticides were examined on both enzymes. For this purpose, firstly, activity assays in varying concentrations of 5 different inhibitors were done and half maximal inhibitory concentrations $\left(\mathrm{IC}_{50}\right)$ were calculated by drawing [I]-\% activity graphs. For each pesticide exhibiting inhibitory effect, activity assays were made in three different inhibitory concentrations at five different substrate concentrations in order to determine inhibition types and $\mathrm{K}_{\mathrm{i}}$ coefficients, Lineweaver-Burk graphs were drawn (Lineweaver and Burk, 1934). All graphs were created with Microsoft Excel program.

\section{RESULTS AND DISCUSSION}

In this study inhibitory effects of cypermethrin, chlorpyrifos, glyphosate isoproplyamin, dichlorvos and lambda-cyhalotrin pesticides on activities of GR and GST purified from turkey liver were examined. For this propose firstly GR and GST were purified from turkey liver (Table 1 and Figure 1).

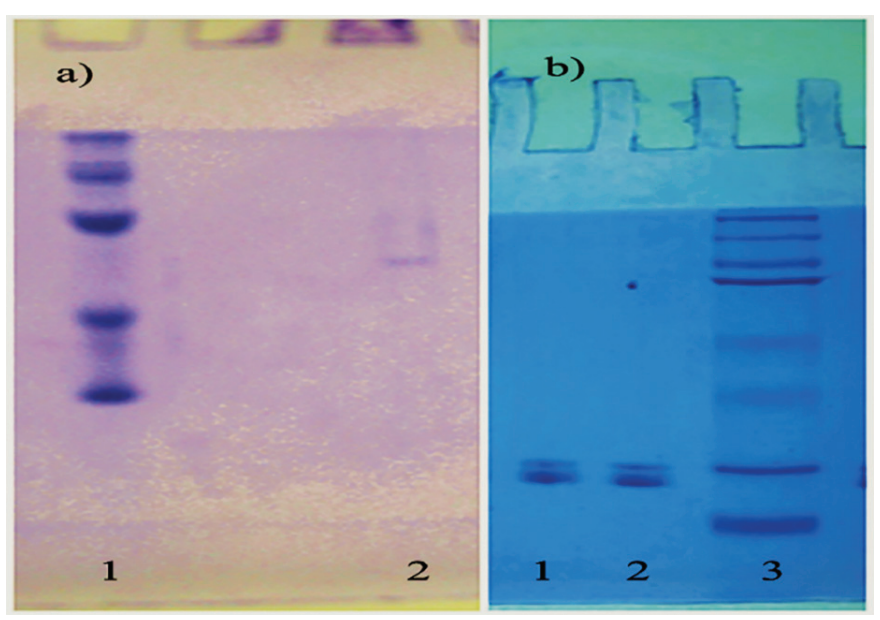

Figure 1 a) SDS-PAGE photo of GR, Line 1: standart proteins (200 kDa, $97 \mathrm{kDa}, 66 \mathrm{kDa}, 45 \mathrm{kDa}, 29 \mathrm{kDa})$, line 2: GR from affinity column b) SDS-PAGE photo of GST, Line 1 and 2: GST from affinity column, line 3: standart proteins (20 kDa, $25 \mathrm{kDa}, 37 \mathrm{kDa}, 50 \mathrm{kDa}, 75 \mathrm{kDa}$, $100 \mathrm{kDa}, 150 \mathrm{kDa}$, and $250 \mathrm{kDa})$ 
Pınar GÜLLER et al.

Table 1. Purification steps of glutathione reductase and glutathione S-transferase enzymes from turkey liver

\begin{tabular}{|c|c|c|c|c|c|c|c|c|c|}
\hline Enzymes & $\begin{array}{l}\text { Sample } \\
\text { Type }\end{array}$ & $\begin{array}{c}\text { Total } \\
\text { Volume } \\
(\mathrm{mL})\end{array}$ & $\begin{array}{l}\text { Activity } \\
\text { (EU mL-) }\end{array}$ & $\begin{array}{l}\text { Protein } \\
(\mathbf{m g ~ m L})\end{array}$ & $\begin{array}{l}\text { Total } \\
\text { Protein } \\
\text { (mg) }\end{array}$ & $\begin{array}{c}\text { Total } \\
\text { Activity } \\
\text { (EU) }\end{array}$ & $\begin{array}{c}\text { Specific } \\
\text { Activity } \\
\text { (EU mg-) }\end{array}$ & $\begin{array}{c}\text { Yield } \\
\%\end{array}$ & $\begin{array}{c}\text { Purification } \\
\text { Coefficient }\end{array}$ \\
\hline \multirow{2}{*}{ 건 } & Homogenates & 38 & 0.680 & 2.8 & 106.4 & 25.84 & 0.243 & 100 & 1 \\
\hline & $\begin{array}{l}\text { Affinity } \\
\text { Chromatography }\end{array}$ & 16 & 0.188 & 0.0003 & 0.0048 & 3.008 & 626.67 & 11.64 & 2167.3 \\
\hline \multirow{2}{*}{ 包 } & Homogenates & 21 & 5.152 & 10.32 & 216.72 & 108.192 & 0.499 & 100 & 1 \\
\hline & $\begin{array}{l}\text { Affinity } \\
\text { Chromatography }\end{array}$ & 5 & 5.17 & 0.111 & 0.555 & 25.85 & 46.57 & 23.89 & 93.32 \\
\hline
\end{tabular}

GRs of diff erent origins have similar molecular weights as follows; $55 \mathrm{kDa}$ (homodimer) and 66 $\mathrm{kDa}$ (homodimer) from mouse liver and human erythrocytes by SDS-PAGE respectively (Douglas, 1987; Tekman et al., 2008).
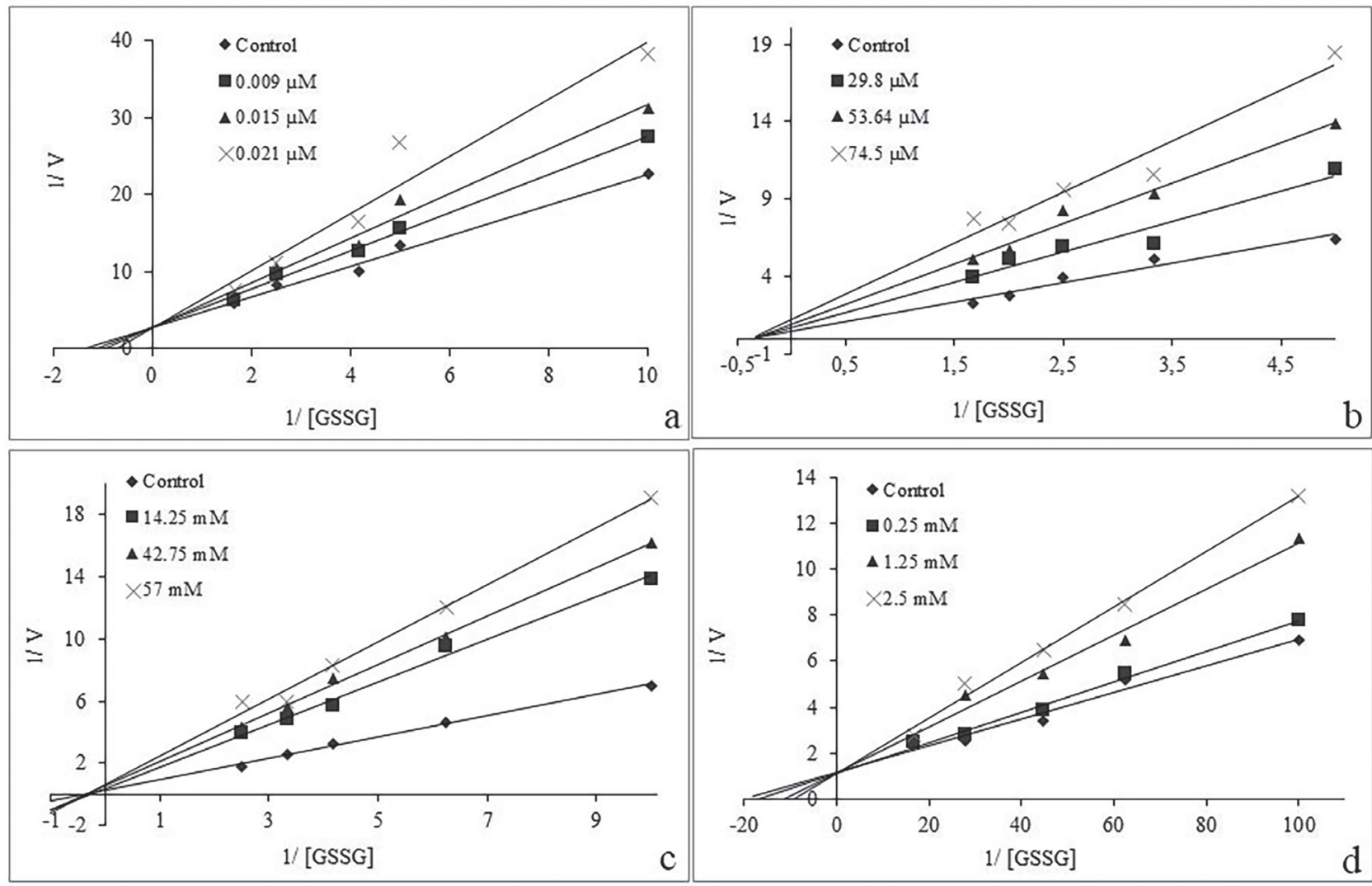

Figure 2. Lineweaver-Burk graphs in 5 different substrate (GSSG) concentrations and in 3 different pesticide concentrations [a) Cypermethrin b) Chlorpyrifos c) Glyphosate isoproplyamin d) Dichlorvos] for determination of $\mathrm{K}_{\mathrm{i}}$ for pesticides on turkey liver GR activity

For turkey liver GR, it was observed that lambda-cyhalotrin did not influence the activity. When particular concentrations of cypermethrin, chlorpyrofos, dichlorvos and glyphosate isoproplyamin pesticides were given to the enzyme, half maximal inhibitory concentrations $\left(\mathrm{IC}_{50}\right.$ values), $\mathrm{K}_{\mathrm{i}}$ coefficients and inhibition types (they were found from Lineweaver Burk graphs (Figure 2)) were determined as shown in Table 2. 
Table 2. The inhibitory effects of the pesticides on turkey liver GR and GSTenzyme activity

\begin{tabular}{|c|c|c|c|c|}
\hline Enzyme & Pesticide & $\mathrm{IC}_{50}$ & $\mathbf{K}_{\mathrm{i}}$ & Inhibition Type \\
\hline \multirow{4}{*}{ 全 } & Cypermethrin & $1.79 \mu \mathrm{M}$ & $0.022 \pm 0.002 \mu \mathrm{M}$ & Competitive \\
\hline & Chlorpyrifos & $40.59 \mu \mathrm{M}$ & $52.303 \pm 2.95 \mu \mathrm{M}$ & Noncompetitive \\
\hline & Dichlorvos & $1.79 \mathrm{mM}$ & $2.04 \pm 0.338 \mathrm{mM}$ & Competitive \\
\hline & Glyphosate isoproplyamin & $32.86 \mathrm{mM}$ & $27.78 \pm 11.5 \mathrm{mM}$ & Noncompetitive \\
\hline \multirow{5}{*}{ 苟 } & Lambda-cyhalotrin & $0.128 \mathrm{mM}$ & $0.122 \pm 0.036 \mathrm{mM}$ & Noncompetitive \\
\hline & Cypermethrin & $0.163 \mathrm{mM}$ & $0.22 \pm 0.118 \mathrm{mM}$ & Noncompetitive \\
\hline & Chlorpyrifos & $0.715 \mathrm{mM}$ & $0.556 \pm 0.11 \mathrm{mM}$ & Noncompetitive \\
\hline & Dichlorvos & $2.16 \mathrm{mM}$ & $2.098 \pm 0.073 \mathrm{mM}$ & Noncompetitive \\
\hline & Glyphosate isoproplyamin & $43.12 \mathrm{mM}$ & $15.37 \pm 6.88 \mathrm{mM}$ & Competitive \\
\hline
\end{tabular}

For turkey liver GST, it was found that all pesticides caused inhibition on the enzyme GST purified from turkey liver. $\mathrm{IC}_{50}$ values of pesticides, $\mathrm{K}_{\mathrm{i}}$ coefficients and inhibition types (they were found from Lineweaver Burk graphs (Figure 3) were determined as shown in Table 2.

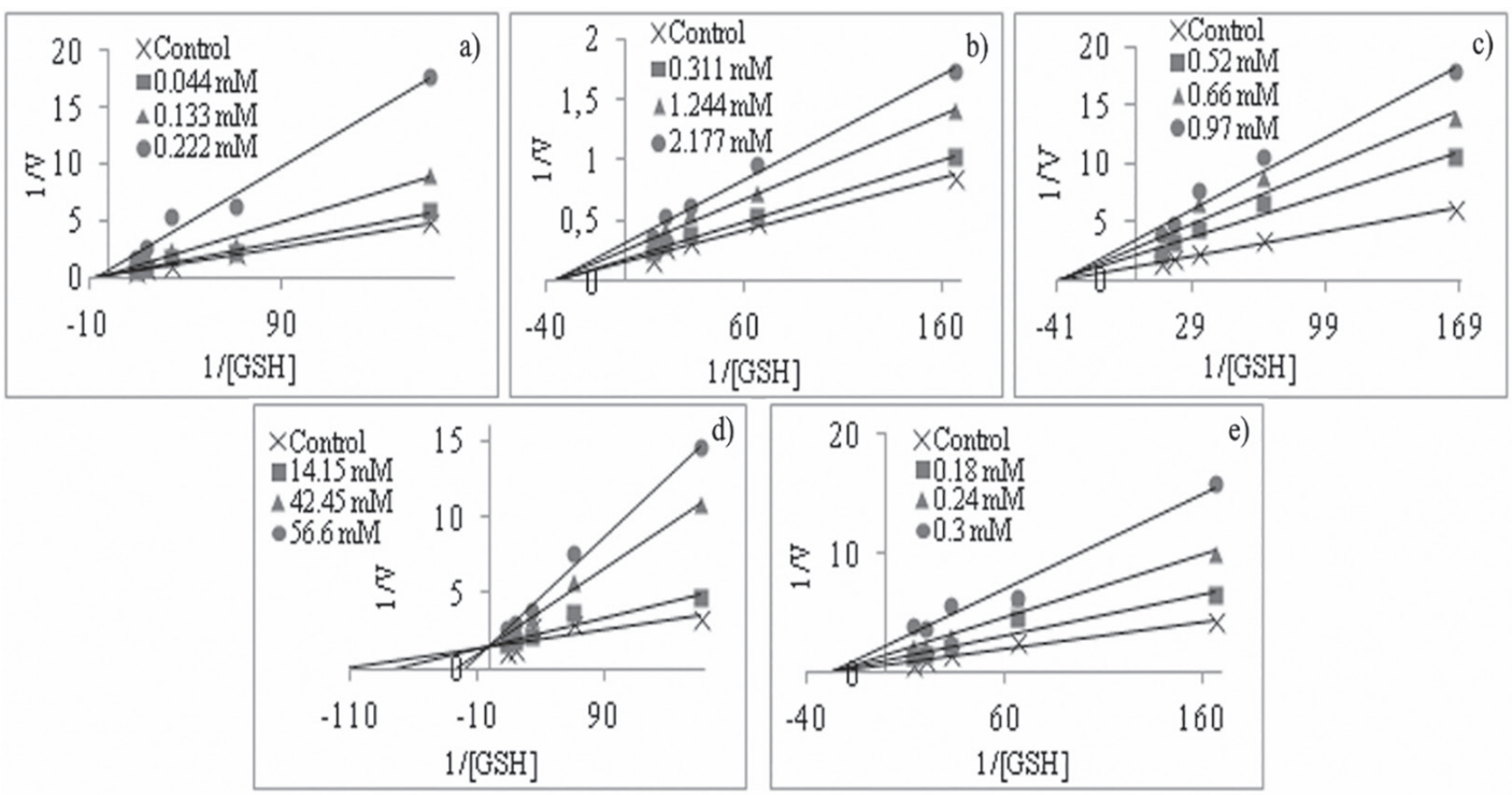

Figure 3. Lineweaver-Burk graph in 5 different substrate (GSH) concentrations and in 3 different pesticide concentrations [a) Lambdasihalotrin b) Dichlorvos c) Chlorpyrifos d) Glyphosate isopropylamin e) Cypermethrin] for determination of $\mathrm{K}_{\mathrm{i}}$ for pesticide on turkey liver GST enzyme activity

While use of agrochemicals increase agricultural fertility, its unconscious and misuse causes human and environmental health problems. When pesticides are used in dosages over the recommended dosages, when they are used with mixing it more than one chemical unless necessary or when the time between the last disinfection and harvest season is not obeyed, it may leave remnants in large amounts in food products. In 
people and other living creatures who are nourished with these foods, it may cause acute or chronic poisonings, as well as flavour and quality changes may occur especially in some products (Henning et al., 1954). Additionally, extistence parameters of pesticides and total pesticides in waters according to "Provisions Concerning Drinking-Tap Water" of "Regulation Concerning Water Intended For Human Consumption" were determined to be $0.1 \mu \mathrm{gL}^{-1}$ and 0.5 $\mu \mathrm{gL}^{-1}$, respectively (http://www.resmigazete.gov.tr/).

When the literature was examined, it was observed that the inhibition effect of pesticides, metal ions and anions as environmental pollutants were investigated on some enzymes. Especially, the inhibition effects of metal ions have been investigated on GST, an important enzyme of detoxification metabolism, after purification from various sources (Güller et al., 2014; Özaslan et al., 2017; Aksoy et al., 2017).

Gultekin et al. have shown the in vitro inhibition effect of chlorpyrifos-ethyl on the antioxidant enzymes; catalase (CAT), glutathione peroxidase (GPx) and superoxide dismutase (SOD) and they observed that the activity of all three enzymes was affected significantly (Gultekin et al., 2000). The inhibitory effects of organotin compounds; tributyltin (TBT), triphenyltin (TPT) and dibutyltin (DBT) on tropical marine fish tissues GST activity were investigated in a study conducted by Al-Ghais and Ali 1999 and they found that the enzyme inhibitory potency of organotins was in the order of TBT $>$ TPT $>$ DBT (Al-Ghais and Ali 1999). In another study conducted by Sentürk et al., 2009, the inhibitory effects of deltamethrin, cypermethrin and propoxur pesticides on glucose-6phosphate dehydrogenase enzyme were investigated and $\mathrm{K}_{\mathrm{i}}$ constants were found to be $1.84 \pm 0.33$, $2.63 \pm 0.18$ and $16.55 \pm 0.35 \mathrm{mM}$, respectively, while the inhibition types were found to be noncompetitive and uncompetitive (Şentürk et al., 2009). In another study, the effects of deltamethrin, diazinon, propoxur and cypermethrin pesticides on human erythrocyte carbonic anhydrase activity were investigated and $\mathrm{IC}_{50}$ values were found to be $0.137,0.267,0.420$ and 0.460 $\mu \mathrm{M}$, respectively. Cypermethrin has been found to have the least effect (Ceyhun et al., 2010). In another in vitro study, the effects of ethidium, chlorpyrifos, dimethoate and monocrotophos pesticides were studied, and it was observed that GR and GST activities were increased but
G6PD activity was decreased (Singh et al., 2006). As in previous studies, pesticides in our study inhibited two important enzymes in question. However, there was shown significant differences in dosage. The reason for this is thought to be due to differences in amino acid structure between species in enzyme.

Inhibition occuring in GR activity means that transformation of GSSG into GSH will be interrupted. This situation also affects GPx and GST activities which use GSH. As a result of being unable to inactivate free radicals and xenobiotics, structures of cellular membrane and organelles may be damaged due to structures of proteins, lipids and carbohydrates. As a result of this, cell death or development of tumor may arise. Additionally, GSSG not to be able to be reduced also leads to hemolysis of erythrocytes. In our country, some studies have been focused especially on foods intended for consumption. In researches conducted in regions in which pesticide use is extensive, pesticide remnants were encountered in majority of obtained milk samples, the obtained amounts were determined to be obviously over the tolerance margins. Worse is that it has been thought that these pesticide remnants in the milk may lead to more serious dangers in terms of human health by being condensated during processing of milk to concentrated products such as cream, cheese and butter (Ceylan, 1977). Similarly, in researches in which pesticide remnants in fruits and vegetables were examined, it was determined that some fungisides had negative effects on flavour of the product and fermantation and hence lactic acid formation was prevented in pickles to which pesticide was applied. In bread obtained from wheat to which pesticide was applied, it was observed that pesticide remnant did not completely removed (Durmusoglu, 2003).

\section{CONCLUSION}

In this study GR enzyme was purified having a specific activity of $626.67 \mathrm{EU} \mathrm{mg}-1$ proteins, with a yield of $11.64 \%$ and 2167.3 fold and GST enzyme was purified having a specific activity of $46.57 \mathrm{EU}$ mg-1 proteins, with a yield of $23.89 \%$ and 93.32 fold. While cypermethrin was the most effective inhibitor for GR, GST was inhibited strongly by lambda-cyhalotrin. This study showed that dichlorvos, chlorpyrifos, glyphosate isopropylamin, cypermethrin pesticides are potent inhibitors for turkey liver GR and GST enzymes. 


\section{REFERENCES}

Akkemik E, Taser P, Bayindir A, Budak H, Ciftci M, 2012. Purification and characterization of glutathione S-transferase from turkey liver and inhibition effects of some metal ions on enzyme activity. Environmental Toxicology and Pharmacology, 34: 888-894.

Aksoy M, Özaslan MS, Küfrevioğlu OI, 2016. Purification of glutathione S-transferase from Van Lake fish (Chalcalburnus tarichii Pallas) muscle and investigation of some metal ions effect on enzyme activity J Enzyme Inhib Med Chem, 31(4): 546-550.

Alaa AM, Manal HA, Manal EA, Halwagy E, Mostafa M, Afify M, 2011. A study on oxidative stress biomarkers and immunomodulatory effects of pesticides in pesticide-sprayers. Egyptian Journal of Forensic Sciences, 1: 93-98.

Al-Ghais, SM, Ali B, 1999. Inhibition of Glutathione S-Transferase Catalyzed Xenobiotic Detoxication by Organotin Compounds in Tropical Marine Fish Tissues Bull. Environ. Contam. Toxicol. 62:207-213.

Armstrong RN, 1997. Structure, catalytic mechanism, and evolution of the glutathione transferases. Chemical Research in Toxicology, 10(1): 2-18

Bhuvarahamurthy V, Balasubramanian N, Govindasamy S, 1979. Effect of radiotherapy and chemoradiotherapy on circulating antioxidant system of human uterine cervical carcinoma. Molecular and Cellular Biochemistry, 158(1): 17-23.

Burçak AA, 2012. İlaç, Alet ve Toksikoloji Araştırmaları Çalışma Grubu, Bitki Sağlığı Araştırmaları Daire Başkanlığı T.C. Tarım Gıda ve Hayvancılık Bakanlığı. http://www.tarim.gov.tr/ TAGEM/Belgeler/SUNULAR

Carlberg I, Mannervik B, 1975. Purification and characterization of the flavoenzyme glutathione reductase from rat liver. The Journal of Biological Chemistry, 250: 5475- 5480.

Ceyhun SB, Sentürk M, Erdoğan O, Küfrevioğlu ÖI, 2010. In vitro and in vivo effects of some pesticides on carbonic anhydrase enzyme from rainbow trout (Oncorhynchus mykiss) gills Pesticide Biochemistry and Physiology 97, 177-181.

Ceylan S, 1977. Klorlu hidrokarbon rezidülerinin süt, tereyağı, peynir ve iç yağlannda kramotografik yöntemlerle araştınlması. Ankara Üniversitesi Veteriner Fakültesi Dergisi, 24(2): 296-318.

Dilek ON, 2003. Serbest Radikaller ve Cerrahi. Serbest Radiakaller ve Antioksidanlar Araştırma Derneği III.Ulusal Kongresi: 23-30 Mart,Afyon.

Douglas, K.T.,1987. Mechanizm of glutathione-dependent enzymes., Meister, A.,(ed). Avdan. Enzymol., Johm Wiley and Sons inc., New York. 59, 103-167.

Durmusoglu E, 2003. Market basket monitoring of some organophoshorus pesticides on apple and strawberry in Izmir province, Turkey. Archiv für Lebensmittelhygiene. 54(1): 16-19.

Fridovich I, 1976. In free radical in biology. In: Pryor W A (Ed.), Academic, 1. Edt., New York, USA. 239-271.

Gultekin F, Ozturk M,Akdogan M, 2000. The effect of organophosphate insecticide chlorpyrifos-ethyl on lipid peroxidation and antioxidant enzymes (in vitro). Archives of Toxicology, 74: pp 533-538.

Güller U, Taşer P, Ciftci M, Küfrevioğlu Öİ, 2014. Purification of Glutathione S-Transferase From Bonito (Sarda Sarda) Liver And Investigation of Metal Ions Effects on Enzyme Activity. Hacettepe J. Biol. \&Chem., 42 (3),435-442.
Habig WH, Pabst MJ, Jakoby WB, 1974. Glutathione S- transferases. The first enzymmatic step in mercapturic acid formation. Journal of Biological Chemistry, 246: 7130-7139.

Halliwell B, 2007. Biochemistry of oxidative stress. Biochemical Society Transactions, 35(5): 1147-1150.

Hayes JD, Pulford DJ, 1995. The glutathione S-transferase supergene family: regulation of GST and the contribution of the isoenzymes to cancer chemoprotection and drug resistance. Critical Reviews in Biochemistry and Molecular Biology, 30: 445-600.

Henning JC, Davis AC, Robinson WB, 1954. Flavor and color evaluation of canning crops grown in soil treated with insecticides. Journal of Food Science and Technology, 8: 227.

http://www.resmigazete.gov.tr/eskiler/2013/03/20130307-7.htm

Keha EE, Küfrevioglu Öİ, 2012. Biyokimya. Aktif Yayınevi. 9. Bask1, Erzurum, Türkiye. $643 \mathrm{~s}$.

Kovesdy CP, Kalantar-Zadeh K, 2009. Review article: Biomarkers of clinical outcomes in advanced chronic kidney disease. Nephrology (Carlton), 4(4): 408-415.

Lineweaver H, Burk D, 1934. The determination of enzyme dissocation constants. Journal of the American Chemical Society, 57: 685.

Özaslan MS, Demir Y, Küfrevioğlu OI, 1 Çiftci M, 2017. Some metals inhibit the glutathione S-transferase from Van Lake fish gills J BiochemMol Toxicol.;31:e21967.

Romero FJ, Bosch-Morell F, Romero MJ, Jareno EJ, Romero B, Marin N, Roma J, 1998. Lipid peroxidation products and antioxidants in human disease. Environmental Health Perspectives, 106(5): $1229-1234$

Sabuncuoğlu S, Özgüneş H, 2011. Kemoterapi, Serbest Radikaller ve Oksidatif Stres. Hacettepe Üniversitesi Eczacilık Fakültesi Dergisi, 31(2): 137-150.

Sentürk M, Ceyhun SB, Erdoğan O, Küfrevioğlu ÖI, 2009. In vitro and in vivo effects of some pesticides on glucose-6phosphate dehydrogenase enzyme activity from rainbow trout (Oncorhynchus mykiss) erythrocytes Pesticide Biochemistry and Physiology 95 95-99.

Singh M, Sandhir R, Kiran R, 2006. Erythrocyte antioxidant enzymes in toxicological evaluation of commonly used organophosphate pesticides, Indian journal of Experimental Biology, 44; 580-583.

Taşer P, Ciftci M, 2012. Purification and characterization of glutathione reductase from turkey liver. Turkish Journal of Veterinary and Animal Sciences, 36(5): 546-553.

Tekman B, Ozdemir H, Senturk M, Ciftci M, 2008. Purification and characterization of glutathione reductase from rainbow trout (Oncorhynchus mykiss) liver and inhibition eff ects of metal ions on enzyme activity. Com. Biochem. Physiol. C; 148: 117-121.

Tiryaki O, Canhilal R, Horuz S, 2010. The use of pesticides and their risks. Erciyes Üniversitesi Fen Bilimleri Enstitüsü Dergisi, 26(2): 154-169.

Wildburger R, Mrakovcic L, Stroser M, Andrisic L, Borovic SS, Zarkovic K, Zarkovic N, 2009. Lipid peroxidation and ageassociated diseases-cause or consequence? Review Citation. Türkiye Klinikleri Tıp Bilimleri Dergisi, 29(1): 189-193.

Yıldız M, Gürkan O, Turgut C, Kaya Ü, Ünal G, 2005. Tarımsal Savaşımda Kullanılan Pestisitlerin Yol Açtığı Çevre Sorunları VI. Türkiye Ziraat Mühendisliği Teknik Kongresi. TMMOB Ziraat Mühendisleri Odası, Ankara. 